B 4300551
$\mathrm{QH}$
31
D7
B2

MEMOIR

OF

JOHIN WILLIAM DRAPER.

$I 8 I I-I 882$. 


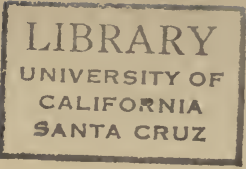



Digitized by the Internet Archive in 2007 with funding from Microsoft Corporation 



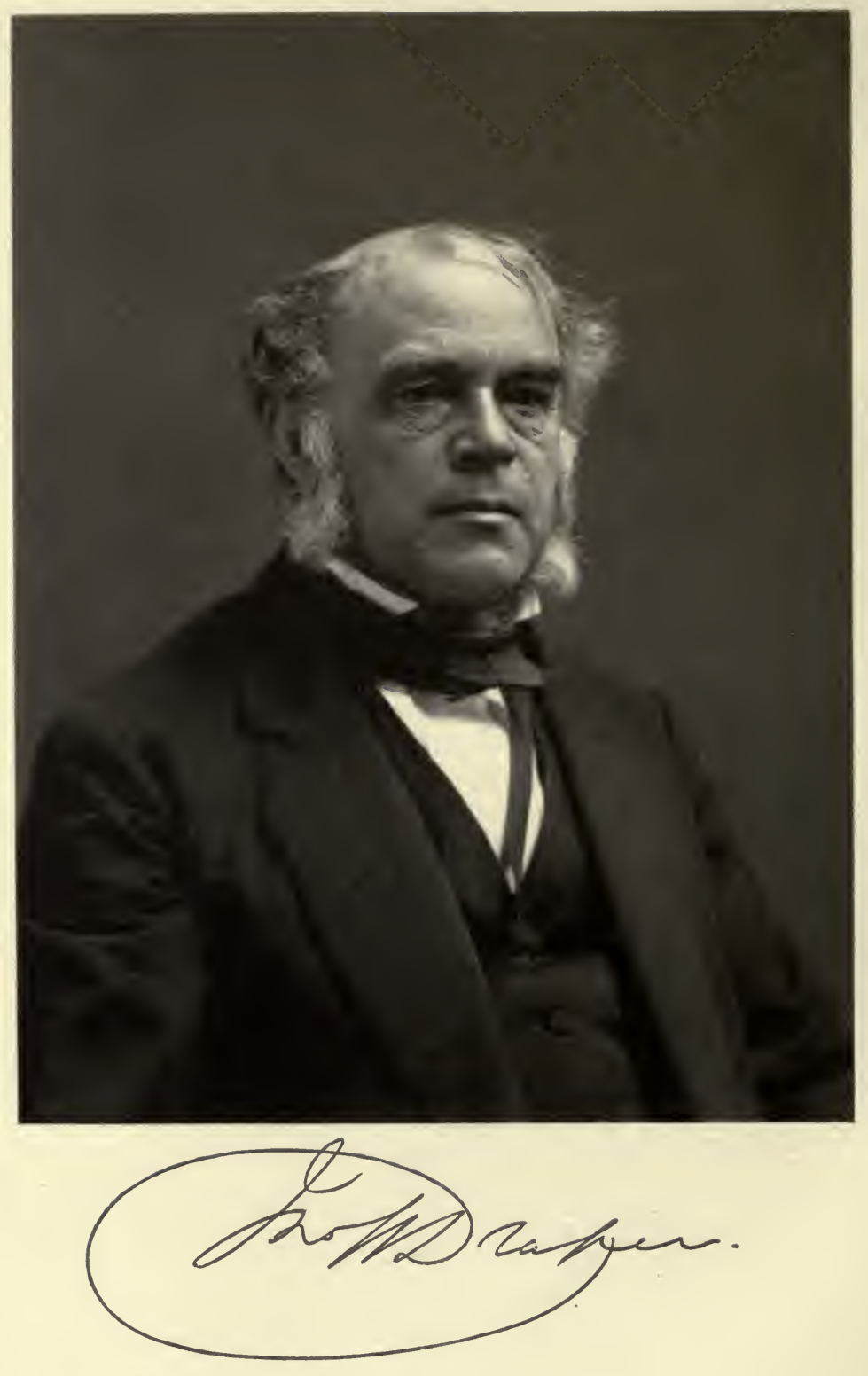





\section{BIOGRAPHICAL MEMOIR OF JOHN WILLIAM DRAPER.}

\section{Mr. Presinent and Grentlemen of the Academy :}

The growth of science during the last half century is nowhere better illustrated than in the changes which have taken place in our views with regard to the doctrine of energy. Fifty years ago the imponderables held full sway and heat light and electricity were considered forms of matter quite as much as oxygen and sulphur and iron. True here and there an advanced thinker offered his protests against this conception and even made experiments to prove its fallacy ; but it was not until 1844 that Melloni established the essential identity of radiant light and heat, and not until 1850 that Foucault made his experimentum crucis with regard to light. No one in America, it is believed, had a larger share in contributing to this entire revolution of scientific opinion than the eminent man who is the subject of this notice. For more than forty years he labored earnestly, persistently, successfully in the field of radiant energy. Viewed from the standpoint of to-day much of his work may be criticised, of course; but, as he himself has said, to an observer " imbued with the true spirit of philosophy even the shortcomings which are detectable in it are not without a charm. From the better horizon he has gained he watches his author, who, like a pioneer, is doubtfully finding his way, here traveling on a track that leads to nothing, then retracing his footsteps, and again, undeterred, making attempts until success crowns his exertions. To explore the path to truth implies many wanderings, many inquiries, many mistakes."

Join Wildiam Draper was born in the parish of St. Helens, near Liverpool, England, on the 5th of May, 1811. His father, the Rev. John C. Draper, was a clergyman of the Wesleyan denomination and, like others in the same calling, was in quite moderate circumstances. He was always greatly interested in scientific subjects, however, especially in chemistry and astronomy, and owned a Gregrorian reflecting telescope, with which he made . 
many observations. Young Draper received his earlier education in his own home from private tutors employed for the purpose; but at the age of eleven he was sent to a public school at Woodhouse Grove, then supported by the Wesleyans. The head master of this school was an American. He was a man of considerable literary ability and had contributed several articles of note to Rees' Encyclopedia, an authority then in great repute. Here young Draper devoted himself assiduously to his classical and mathematical studies and with marked success. So that, in recognition of the progress he had made in scholarship, he was selected in 1824 to deliver the customary address from the school to the Wesleyan conference, which met that year at Leeds. This was his first public oration and it made a great impression upon him. Not long after this event, however, he left the Woodhouse Grove school and returned home, continuing his studies there, as before, under private tutors.

In the year 1829 the University of London was opened for instruction. The professor of chemistry in the new institution was Dr. Edward Turner, a man whose reputation as a chemist placed him among the first in England. Young Draper, who, with his other studies, had taken up the study of science and had already developed a decided taste for investigation, was sent to Dr. Turner's laboratory to receive a course of instruction in chemistry. During the two or three years which were thus occupied a pleasant and profitable acquaintance was engendered, which ripened into a lifelong friendship. Owing to the unexpected death of his father, however, he did not take a degree at the University.

Before the Revolutionary IVar certain of Draper's ancestors on his mother's side had come to America and had settled in Virginia, founding a small Wesleyan colony. Subsequently others of the family had crossed the ocean and joined the colony. Urged by these relatives and accompanied by his mother and sister Draper came to America in 1832, in his twenty-second year. The expectation of receiving a professorship in the denominational college in the vicinity was one of the strongest inducements held out to him. Repeated delays in starting, however, made the time of his arrival much later than had been anticipated; so that, when he reached Virginia, the position he had hoped for had been given to another person. He settled with his relatives at Christiansville, Mecklenburg county, where he devoted himself entirely to scientific research.

Although before laving England he had published, jointly with 
a Fellow of the Geological Society, three papers on scientific subjects, yet his first independent contribution to science was from this Christiansville laboratory. It appeared in the American Journal of Science and Arts for July, 1834, in the form of a letter to the editors, the memoir in extenso appearing in the September number of the Franklin Institute Journal for the same year under the title "Some experimental researches undertaken to determine the nature of eapillary action." During this period he devoted his attention also to improvements in the construction of galvanic batteries, to investigations on the alleged magnetic action of light, and to the analysis of a native chloride of carbon and of certain ancient coins and medals.

Having decided to take the degree of Doctor of Medicine in course Draper spent the winters of 1835 and 1836 in Philadelphia attending the medical lectures given in the University of Pennsylvania. Here he came directly under the congenial and stimulating influence of Dr. Robert Hare's instruction in chemistry and physies, and in him and in Dr. J. K. Mitchell, at that time the professor of chemistry in the Jefferson Medical College, he found warm personal friends. In their laboratories he did a large amount of scientific work, and this not only alone, but also conjointly with these eminent men. He assisted Dr. Mitchell when he used for the first time in this country the apparatus of Thilorier for the liquefaction of carbonicacid gas.

Draper graluated from the University in March, 1836. 'The subject of his thesis, as given in the Alumni Catalogue, was "Glandular Action." It discussed the passage of gases through various barriers not having visible pores, such as soap bubbles. He showed that these transfusions take place as instantaneously as if there was no obstacle in the way and are attended by many curious phenomena. He put one gas inside the bubble and another on the outside; he then analyzed both and showed that the movement continues until the gaseous constitution is the same within and without the bubble. The special application of these experiments was to ascertain what goes on in the air cells of the lungs; how oxygen is introduced into the blood and carbonic acid escapes from it in the act of inspiration. Current report has it that the scientific character of this thesis secured for it the special commendation of the medical faculty and the high honor of publication at their hands. But as the thesis itself is missing from the collection of the class of 1836 , preserved 
in the college records, and as no such title as the above appears in any of his published papers, it has been found impossible.to verify the statement. Two papers, however, covering much the same ground appeared shortly afterward. The first, "Experiments on Endosmosis," came out in the Journal of the Franklin Institute for March and July. The second, entitled "Experiments on Absorption," which was much more extended, was printed in the American Journal of the Medical Sciences for May.

The published scientific memoirs of Dr. Draper had now won for him a very considerable reputation. His graduating thesis had by its originality and by the experimental ability shown in it attracted the attention of the authorities of Hampden Sidney College, Prince Edward county, Virginia. Accordingly, in the fall of 1836, he was tendered, and accepted, the professorship of chemistry and natural philosophy in that institution. This appointment was especially agreeable to him, since it enabled him, as he said, "to convert experimental investigation, thus far only an. amusement, into the appropriate occupation of his life." In the new sphere of labor thus opened to him he continued his scientific researches with largely increased experimental facilities.

In 1837 a movement was made to establish a medical school in connection with the University of the city of New York, and Dr. Draper was elected professor of chemistry in the new institution. The financial embarrassments of that year, however, crippled the university and the project was temporarily abandoned.

In 1839, however, he was elected professor of chemistry in the undergraduate department of that university, and removed with his family to the city of New York. In 1840, in conjunction with Drs. Mott, Bedford, Pattison, and Revere, he took an active part in organizing the medical department, in which he became the professor of chemistry. His intimate relations with the chancellor, the Hon. Theodore Frelinghuysen, resulted in his assuming a large share in the preparation of the constitution of the new department, to the wise provisions in which its subsequent prosperity has been largely due. Moreover, in doing this he exerted a marked influence on the development of medical science in the city of New York. At that time there were but few medical students there, probably not more than forty or fifty. But in the session of 1841'42 the University Medical School alone enrolled 239 students, and the number in attendance at the College of Physicians and Sur- 
geons was also largely increased. The new movement was, from the first, greatly indebted to the influence exerted in its favor by the New York Herald; and this arose out of the relations of personal friendship which existed between Dr. Draper and Mr. James Gordon Bennett. To these gentlemen, it has been said, more than to any others, New York owes its present advanced position as regards medical education. Entire pages of the Herald were devoted to reports of the lectures and clinics at the University; and a strictly medical journal, published by Mr. Bennett and called The Lancet, kept the doings of the University school constantly before the medical profession.

The first president of the new medical college was Dr. Valentine Mott, who was also professor of surgery. Dr. Draper was elected secretary. In 1850, upon the resignation of Dr. Mott, he succeeded to the presidency, and by his active measures and wise counsels, inaugurated a period of unexampled prosperity for it. In his own instruction Dr. Draper had always maintained that the functions of an organized being were performed under the operation of chemical and physical law, in opposition to the theory of vital force then in vogue among physiologists. And now, when the new views of Liebig and his school gave increased importance to the chemical relations of physiology, he was among the first to recognize their value, and, as a consequence and at his request, physiology was added to his chair. He resumed his researches on physiological subjects, and his lectures were replete with novel and radical ideas.

One of the severest trials through which the medical department was called to pass during Dr. Draper's presidency was the entire destruction by fire, in 1865, of its college building in Fourteenth street. But the same untiring energy which had secured the edifice that was destroyed not only made prompt provision for the continuance of the lectures, but speedily repaired the loss. Though in the midst of the course of instruction, not a single lecture was lost; and in the fall of 1869 he gave the introductory lecture of the course in the new building, which is still occupied by the school, and which had been provided, as he told the class, by the generosity of $\mathrm{Mr}$. Courtlandt Palmer.

Dr. Draper's personal loss was especially severe. Not only were his extensive library, his lecture notes, and the note-books which contained the results of his experimental investigatious consumed, but his entire collection of chemical, physical, and physiological 
apparatus, that used to illustrate his lectures as well as that more valuable portion which he had used in his researches, was destroyed. The pecuniary loss he estimated at $\$ 15,000$. This was the second time he had suffered severely by fire. In 1853 almost the entire edition of his scientific memoirs and essays up to 1844 , together with the illustrative plates, were destroyed by fire in the publishing house of Harper \& Brothers.

In 1873 Dr. Draper severed his connection with the medical department of the University, but continued his instruction in chemistry to the undergraduate classes until 1881, the year preceding his death.

It has been already stated that Dr. Draper developed very early in life a decided fondness for science and scientific investigation. It is said that his decision to devote himself to the experimental study of nature arose from the accidental observation that in a glass vessel containing camphor beautiful crystals had condensed only on the illuminated side. A desire to understand the cause of this phenomenon led him to read whatever books he could obtain which treated of the chemical and mechanical action of light, of adhesion and of capillary attraction, and subsequently to experiment for himself in these and similar subjects.

Capillary attraction was the subject of his first extended research. Clairaut had already shown that the phenomenon was due to the adhesion of the solid for the liquid as compared with the cohesion of the latter, and that if the mutual attraction of a solid and a liquid amount to half the cohesion of the liquid there will be capillary depression; but that if this attraction be greater than half the cohesive value the liquid will rise in the tube. Dr. Young had maintained that the bounding meniscus of a liquid was an elastic surface and acted by its tension to elevate or depress the column which it terminated. And Laplace, in the more elaborate memoir contained in his Théorie de l'action Capillaire, published in the supplement to the tenth book of his Mécanique Celeste, had attributed the rise or fall of liquids to the attraction of a thin layer of the liquid immediately adjacent to the walls of the tube. Dr. Draper's attention was first drawn to the subject, as he tells us, during those tiresome moments of returning health which follow an autumnal fever. "Perhaps," he says, " if there be any merit in these experiments it may hereafter be of service to some one to know that they were begun in sickness and in a land of strangers; that they 
were pursued in all the calamity of family bereavement, and in the depths of forests, alike unused to music, to poetry, to philosophy." His first experiments were addressed to the direct determination of the attraction between mercury and glass, with the view of testing Clairaut's mathematical deduction. After repeated trials he found that a strong and uniform adhesion was obtained when the mercury was pure and warm and the glass perfectly clean. Repeating the experiment with an amalgamated disk of copper, of the same size, the weight required for separation was regarded as measuring the cohesion of the mercury itself. The results of a number of experiments showed that in no case did the attraction of mercury for glass amount to half the cohesion of the mercury. But since a glass plate on the surface of water is wetted, even after separation, it is obvious that in this case the adliesion is greater than the whole cohesion; hence the rise of water in a tube of glass is easily accounted for.

But an unexpected phenomenon was developed. On connecting the mercury, dry and warm, to a gold leaf electroscope no disturbance of the leaves took place so long as the glass plate was in contact with its surface. But on separating them-and it required considerable force to do this-both the mercury amd the glass became strongly electrified, the mereury being negative and the glass positive. Indeed, the development of electrification was so decided as to tear asunder the leaves of the electroscope. Dr. Draper naturally concluded that contact of mercury and glass developed electrification ; that while in contact the electricity was "disguised" and appeared only on separation; and that since the two were oppositely and strongly electrified, the force required to separate them measured the electrical attraction. But this foree measured also the adhesion, by hypothesis; and hence adhesion must be an electrical attraction. Two striking confirmations of this theory are given in the memoir. In the first he repeated the mercury experiment with disks of glass, gum-lac, sealing wax, sulphur, and beeswax, and proved that the electrification, as measured with the torsion balance, was for each disk proportional to the adhesion as measured by the force required for separation; and that for the several disks examined the values obtained diminished in the above order. In the second he showed very ingeniously that electrification exercises an apparent control over all the phenomena of eapillary attraction. One furm of his apparatus consisted of an inverted siphon, the 
larger leg being about half an inch and the smaller about onetenth of an inch in diameter. Mercury is poured into the larger and dilute sulphuric acid into the smaller tube, the latter liquid resting on the former. On connecting the mercury with the negative terminal of a voltaic battery and the acid with the positive the mercury falls in the tube. Reverse the battery-terminals and the mercury column rises. Moreover, Dr. Draper observes that all these changes in position are accompanied by certain definite changes of figure of the bounding surface, and shows that this might have been expected from the theory of Laplace. Placing a globule of mercury in acidulated water in contact with the negative terminal of the battery he found that whenever eontact of the positive terminal was made with the acid an instant deformation of figure took place, the upper surface being flattened, so that the mercury touched the inclosing tube all around in a complete ring. This memoir, published in 1834, must be considered in all respects a remarkable one, and anticipates clearly many of the more important later discoveries.

The phenomenon of osmose described by Dutrochet in 1827 had been noticed by Dr. Draper in the above memoir. A few years later Dr. J. K. Mitchell had published a valuable paper on the osmotic phenomena observed in membranes of caoutchouc. When Dr. Draper entered upon his medical studies in Philadelphia, therefore, it was natural that he should take a lively interest in the phenomena referred to, and particularly in their physiological relations.

His experiments on gaseous osmose were original and important and were based on the simple assumption that any substance in contact with any other tends to diffuse into it. He found that ammonia gas penetrated almost instantly films of shellac, gold leaf and mica, and especially liquid films, whether these were thin, as in a soap bubble, or were composed of a layer of water of quite considerable thickness. When such a layer separated carbonic:acid and hydrogen gases, for example, he observed that the phenomenon was a simple one and consisted in the mutual solution of the gases in the liquid, their transference through the film, and their subsequent evaporation, the process ceasing when the atmosphere on both sides of the layer was the same. Using then a membrane of caoutchouc he sought to discover whether gaseous osmose could be prevented by pressure; and he experimentally proved that sulphurous acid passed into air under a pressure of $7 \frac{1}{3}$ atmospheres, car- 
bonic acid under one of 10 atmospheres, and hydrogen sulphide under a pressure of 24 atmospheres. Since the force impelling the particles of one gas into the interstices of another, without a septum, never exceeds the pressure of one atmosphere, it is plain that the source of this remarkable power must lie in the membrane itself. So that the eaoutchoue membrane must, in this experiment, have condensed the sulphurous-aeid gas and the hydrogen-sulphile gas into liquids, which were then, in this condition, transferred through the film and evaporated on the other side precisely as with the water film.

With regard to liquid osmose Dr. Draper shows that the only essentials are: First, that both the liquids should wet the barrier; second, that they should rise to difficrent heights in tubes made of it, and, third, should be capable of uniting chemically with each other. All solid bodies which act as barriers have pores, which, while too small to permit leakage, yet allow interchange of indefinitely small columms of liquid. Such are plates of Villarica porcelain elay, of Brazil indurated steatite, and of certain varieties of compact sandstone. No liquid can pass a barrier the pores of which it cannot wet; but, since water by electrifying it positively may be made to wet mercury, electricity modifies osmose. The separation of water from litnus through a membrane having alcohol on its other side, he concludes, is " only a refined kind of filtration, which, probably, may hereafter become of considerable importance in its applications in the arts, as in the separation of coloring matter from solutions, or the preparation of medicines, such as the vegetable alkalies, which should te formed from colorless solutions."

In a paper published in 1846 Dr. Draper applies these principles very ingeniously to explain the circulation of the sap in plants and the blood in animals. Both these motions, he says, depend on the following simple physical principle: "That if two liquids communicate with one another in a capillary tube or in a porous or parenchymatous structure and have for that tube or structure different chemical affinities movement will ensue; that liquill which has the most energetic affinity will move with the greatest velocity and may even drive the other fluid entirely before it.". In the rootlut the phenomenon is simply an usmotic one, a flow taking place from the water without into the mucilaginous sap within, precisely as water flows into gum-water through a loladder. In the leaf the weak ascending watery sap rises to its upper surface and there obtains 
carbonic acid from the air. The sunlight effects the decomposition of this, changing it to a mucilaginous solution. On the principle now indicated the water will drive the mucilaginous solution before it, forcing it back along its proper vessels into the stem. The flow of the sap in plants therefore is controlled by sunlight, since this agent determines the production of the mucilaginous solution, which is the motive power. When the season advances the flow. slackens, because the formation of the elaboraterl sap diminishes. Both in the rootlet and in the leaf consequently the action is due to the fact that two different liquids are brought in coutact with a porous solid, which is wetted by both of them, but unequally. Hence that one which has the greatest affinity for the solid and wets it most perfectly passes most rapidly through it and drives the other one before it. The descent of the elaborated sap is therefore quite as positive an action as the ascent of the unelaborated.

In animals the blood in the arterial capillaries of the systemic circulation is charged with oxygen, which has an intense affinity for the carbon and hydrogren of the walls. In the venous capillaries the blood is charged with carbonic acid having no affinity for these tissues. The arterial blood will drive the venous blood before it, therefore. In the pulmonic system the venous blood is presented to the air cells, for the oxygen in which it has a strong affinity, while the arterial blood which has absorbed this oxygen has no longer any. Movement ensues as before, hut as now the affinities are reversed the flow is from the veins to the arteries. The systemic circulation is due therefore to the oxidizing action of the arterial blood and the flow is from the artery to the vein. The pulmonary circulation is due to the oxidation of the venous blood and the flow is from the venous to the arterial side. Both arise from the common principle that "a pressure will always be exerted by the fluid which is ready to undergo a change upon that which has alrealy undergone it-a pressure which, as there is no force to resist it, will always give rise to motion in a direction from the changing to the changed liquid."

"A true theory," says Dr. Draper, "is like a window of crystal glass, through which we can see all objects in their proper positions and colors and relations, no matter whether they are such as are near or those that are at a distance; no matter whether they are directly before us or enter only obliquely into the field of view. A fictitious theory is like a venetian blind, which has to be set in a 
certain position with respect to the observer and only shows him objects for which it has been adjusted, and those in an unsatisfactory manner; but if he moves to one side or to the other, or endeavors to sec objects which are not lirectly in his way, his view is intercepted, or, perhaps, unless he makes a new adjustment, the light is shut out altogether."

It is, however, by his researches upon Radiant Energy that John IV. Draper is best known in the world of science. In an able memoir on the Production of Light by Heat, published in 1847, he described some ingenious experiments with incandescent platinum, by which he conclusively proved: First, that the temperature at which this metal became incandescent was fixed and constant at $977^{\circ} \mathrm{F}$; ; and, sccond, that various other substances, such as brass, antimony, gas carbon, lead, and the like, all became luminous at the same temperature, which was that of the gun barrel in which they were inclosed. By means of an extemporized spectroscope he examined the platinum as its temperature was gradually raised by the electric current and showed that as this temperature rose trom $1,095^{\circ}$ to $2,130^{\circ} \mathrm{F}$. the spectrum gradually extended itself toward the violet; rays of an increasing refrangibility being successively produced, the frequency of the vibrations increasing with the temperature. In order to bring these observations to a common standard of comparison Dr. Draper originated the simple device of using the sun spectrum with its fixed lines as a reference-spectrum, daylight being reflected to the prism through a narrow aperture occupying exactly the position in which the platinum strip was to be subsequently placed. The relation of the temperature of incandescent platinum to the amount of light emitted by it was also examined, and it was found, photometrically, that at $2,590^{\circ} \mathrm{F}$. the light emitted was more than thirty-six times as much as that given out by the same strip of metal at $1,900^{\circ}$. Moreover, on measuring, by means of the thermo-pile, the total energy radiated from the incandescent strip, he found that if he took the heat radiated at $980^{\circ}$ as unity, that emitted at $2,360^{\circ}$ was 17.8 ; the heat radiated between $1,000^{\circ}$ and $1,300^{\circ}$ being nearly the same in amount as that radiated in passing from common temperatures up to $1,000^{\circ}$. In closing this memoir the author says: "The preceding experiments furnislı an easy means of supplying * * * what might be termed a 'unit lamp.' A surface of platinum of standard dimensions, raised to a standard temperature by a voltaic current, will always emit a constant light. 


\section{NATIONAL ACADEMY OF SCIENCES.}

A strip of that metal one inch long and one-twentieth of an inch wide, connected with a lever by which its expansion might be measured, would yield at $2,000^{\circ}$ a light suitable for most purposes. Moreover, it would be very easy to form from it a photometer by screening portions of the shining surface. An ingenious artist would have very little difficulty, by taking advantage of the movements of the lever, in making a self-acting apparatus, in which the platinum should be maintained at a uniform temperature, notwithstanding any ehange taking place in the voltaic current."

In the following year Dr. Draper published a noteworthy memoir on the production of light by chemical action. In this memoir he investigates by means of the prism the character of the light which is produced by combustion, answering thus his own query, "Can any connection be traced between the chemical nature of a substance or the conditions under which it burns and the nature of the light which it emits?" With a slit, a prism, and an observing tclescope he examined the flames of oil, of alcohol, of aleoholic solutions of boric acid and strontium nitrate, of phosphorus, of sulphur, of carbonic oxide, of hydrogen, of cyanogen, and of arsenetted hydrogen. The flame of the oil was yellow; of the alcohol, pale blue; of the boric acid, green; of the strontium, red; of the phosphorus, yellowish white; of the sulphur and carbonic oxide, blue; of the hydrogen, pale yellow; of the cyanogen, lilac, and of the arsenetted hydrogen, white. "Notwithstanding this diversity of color," he says, "all these flames, as well as many others that I have tried, yield the same result; every prismatic color is found in them. Even in those cases where the flame is very faint, as in alcohol and in hydrogen gas, not only may red, yellow, green, blue, and violet light be traced, but even bright Fraunhoferian lines of different colors." The spectra given by these variously-colored flames were earefully drawn and their peculiarities were pointed out. When, he thus examined the flame of cyanogen he beheld, as he says, "a speetrum so beautiful that it is impossible to deseribe it by words or depict it in eolors. It was crossed throughout its extent by black lincs separating it into well-marked divisions. I could plainly count four red rays of definite refrangibility, followed by one orange, one yellow, and seven green rays, while in the more refrangible spaces were two extensive groups of black lines, recalling somewhat from their position, but greatly exceeding in extent, Fraunhofer's lines $G$ and $\mathrm{H}$ in the sun's rays." He considered the interior lilae cone to be 
the source of the fixed lines of the bright spectrum, and he observed that new lines are developed as the temperature rises. "Do not the various facts here brought forward," he says, "prove that chemical combinations are attended by a rapid vibratory motion of the particles of the combining bodies, which vibrations become more frequent as the chemical action is more iitense?" This memoir may be regarded as one of the earliest contributions to spectrum analysis.

In a subsequent memoir, written in 1857, Dr. Draper uses the following remarkable language: "In other cases dark lines are replaced by bright ones, as in the well-known instance of the electric spark between metallic electrodes. The occurrence of lines, whether bright or dark, is hence connected with the chemical nature of the substance producing the flame. For this reason these lines merit a much more critical examination, for by their aid we may be able to ascertain points of great interest in other departments of science. Thus, if we are ever able to acquire certain knowledge respecting the physical state of the sun and other stars, it will be by an examination of the light they emit." Surely these researches, with the prophetic conclusions which he drew from them, entitle Professor Draper to a recognized position among the pioneers in the science of prismatic analysis.

Some of the earliest of Dr. Draper's investigations were directed to a determination of the various forms of energy which exist in solar light. The chemical action of light was always a fascinating subject to him and he had made many interesting experiments to ascertain the effect of different kinds of light upon chemical change. These chemical actions were investigated in three different directions. The first of these was photography. For many years he had studied the action of light in changing the color of metallic salts, and he had already long been accustomed to apply the photographic process to the solution of physical problems when Daguerre's discovery was announced in 1839. He welcomed the daguerreotype enthusiastically, made a special study of it, and in the same year improved it so much that he took by its means the first portrait of the human face. In these days of rapid emulsion processes the directions he gives for taking a daguerreotype appear interesting. "In the first experiments I made," he says, "the face of the sitter was dusted with a white powder, but a few trials showed that this was unnecessary." "On a bright day and with a sensitive plate portraits can be obtained in the course of five or seven minutes in the 


\section{NATIONAL ACADEMY OF SCIENCES.}

diffused daylight even when an ammonia-sulphate of copper cell is interposed. The hands should never rest upon the chest, for the motion of respiration disturbs them so much as to make them of a thick and clumsy appearance, destroying also the representation of the veins on the back, which, if they are held motionless, are copied with surprising beauty. A person dressed in a black coat and open waistcoat of the same color must put on a temporary front of a drab or flesh color, or by the time that his face and the fine shadows of his woolen clothing are evolved his shirt will be solarized and be blue or even black, with a white halo around it. Owing to the circumstance that yellow and yellowish browns require a long time to impress the substance of the daguerreotype persons whose faces are freckled all over give rise to the most ludicrous results-a white portrait mottled with just as many black dots as the sitter has yellow ones." On the 23d of March, 1840, Dr. Draper presented to the Lyceum of Natural History of New York the first representation of the moon's surface ever taken by photography. The daguerreotype plate was exposed twenty minutes and the image was about an inch in diameter. In this image the places of the dark spots can be indistinctly traced.

The second method by which he studied the action of the chemical rays was based upon the effect which they produced upon chlorine gas. In 1843 he announced to the British Association that this gas underwent a decided modification under the influence of sunlight, in consequence of the absorption of these chemical rays. In virtue of this change in its character it was now able to unite directly with hydrogen, a property not possessed by chlorine kept in the dark. Hence he announced the discovery of a new imponderable in solar light which was analogous to light and heat, and which was the agent producing chemical change. To this new agent he gave the name "tithonicity," the origin of which he thus describes: "The chemical rays are associated with the rays of light, accompanying them in all their movements, originating with them, and, unless disturbed, continuing to exist along with them. But should a compound beam like this fall upon a sensitive surface the chemical rays sink into it, as it were, and lose all their force, and the rays of light are left alone. Photographic results thus obtained from the reposing of the chemical rays on the sensitive surface are not, however, in themselves durable, for the rays escape away under some new form. Tithonus was a beautiful youth whom Aurora fell in love 
with and married in heaven. The fates had made him immortal; but, unlike his bride, in the course of events he became feeble and decrepit, and, losing all his strength, was rocked to sleep in a cradle. The goddess, pitying his condition, metamorphosed him into a grasshopper. 'The fact and the fable agree pretty well, and, indeed, the playful coincidence might be carried much farther. The powers of photography, which bring architectural remains and the forms of statuary so beautifully and impressively before us, might seem to be prefigured by the speaking image of the son of Tithonus and $A u-$ rora that was to be seen in the deserts of Egypt. Besides this such words as tithonoscope, tithonometer, tithonography, tithonic effect, ditithonescence are musical in an English ear." In the same year he described a tithonometer or instrument for measuring these chemical rays based on their action upon chlorine. The apparatus consisted of an inverted siphon tube, the shorter limb of which was closed, the longer drawn out and graduated. By means of wires of platinum sealed into the shorter limb the solution of hydrochloric acid which it contained could be decomposed by a voltaic current, and this limb filled with mixed hydrogen and chlorine gases. When the image of a flame, formed by a convex lens, was caused to fall on the sentient tube the liquid in the longer limb began instantly to descend, moving regularly over the scale so long as the exposure was continued. This instrument, while much simpler, appears to be quite as sensitive as the one described by Bunsen and Roscoe many years later (1856).

The third method which Dr. Draper employed for studying the action of the chemical rays was based on the growth of plants. Already, in 1837, he had investigated the phenomenon of the decomposition of solar light by leaves, and had shown that these leaves absorbed certain rays. But these early experiments were made under colored glasses and were not entirely conclusive, other rays passing simultaneously through the media used. When seeds were made to germinate under these glasses, however, he found that the plants under the red and the violet glasses were as perfectly etiolated as if they had been kept in the dark; while those under the yellow glass promptly assumed a green color and developed rapidly. In order to obviate the objection raised to colored glasses a crop of seeds was caused to germinate in a long box placed in the dark and the young plants were then exposed to the action of a solar spectrum. Those in the yellow speedily turned green, while those in the red 
and in the violet regions remained unaffected. An attempt was then successfully made to effect the decomposition of carbonic-acid by the green parts of plants also placed in the solar spectrum. Water freed from air by boiling was saturated with carbonic acid gas, and in it was immersed grass whose surfaces had been carefully freed of air. Seven tubes thus prepared were placed each in one of the seven colors of the spectrum and carefully observed. In a few minutes after the beginning of the experiment the tubes on which the orange, the green, and the yellow rays fell began to give off minute bubbles of gas, and in an hour and a half sufficient was collected for accurate measurement. Forty-three volumes of gas were produced in the yellow-green, twenty-four and three-fourth volumes in the red-orange, four and one-tenth in the green-blue, one in the blue, and none in the other colors. The memoir in which these results were first published was read to the American Philosophical Society on the occasion of its centennial anniversary in 1843 .

But it was mainly by means of spectrum investigations that $\mathrm{Dr}$. Draper studied the components of radiant energy. In the earlier stages of his work he, in common with his contemporaries, regarded heat and light as imponderable agents, entirely distinct from one another, though coexisting in solar light. In his later memoirs, however, having accepted the essential unity of radiant energy, he discusses with great ability, in his memoir of 1872 , on the distribution of the chemical force in the spectrum, the dependence of the result upon the nature of the surface upon which the light falls. In this memoir he shows: First, that so far from chemical influences being restricted to the more refrangible rays every part of the spectrum, visible and invisible, can produce chemical changes and can modify the molecular arrangement of bodies; and, second, that the rays effective in producing chemical or molecular changes in any special substance are determined solely by the absorptive power of that substance. Thus silver salts, for example, blacken most readily in the more refrangible regions. But even these have their peculiarities. An iodide of silver plate long exposed to the spectrum, with absolute exclusion of extraneous light, is normally darkened in the more refrangible and receives a white stain in the less refrangible regions. If, however, the plate receive weak diffised light during exposure it will be found on developing that every ray that the prism can transmit, from below the extreme red to beyond - the extreme violet, has been active.- Indeed, it was by this very process 
that Dr. Draper, in 1843 , discovered the dark lines $\alpha, \beta, \gamma$ in the ultra-red. Essentially the same results are obtained if the plate is submitted to a weak light for a few moments previous to its exposure to the spectrum. It would seem, therefore, as if the less refrangible rays could reverse the general action of light upon iodide of silver. So that, while every ray of the spectrum is capable of affecting this substance, the more refrangible promote, the less refrangible arrest, this general action of light upon it.

Bitumen and resins also receive impressions from below $\mathrm{A}$ to beyond $\mathrm{H}$, every ray in the spectrum acting. In the bleaching of flowers by light "the rays which are effective in the destruction of any one vegetable color are precisely those which by their union produce a tint complementary to the color destroyed." Chlorine and hydrogen unite under the action of the indigo ray, which is seven hundred times more active than the ultra-red. Dr. Draper concludes, therefore, "that the sensitiveness of any given preparation to light depends on its chemical nature and its optical qualities conjointly, and that it is possible to exalt or diminish the sensitiveness of a given compound by changing its optical relations."

The results of Dr. Draper's investigations with the prismatic spectrum, however, were not altogether satisfactory to him, owing to a defect which originates in the rery cause which gives rise to the spectrum itself-unequal refrangibility. If we compare together two sets of rays, one taken in the red and the other in the violet region, it is obvious that, in the same spectrum, from the very circumstance of their greater refrangibility, those in the violet will be relatively more separated from each other than those in the red. The result of this increased separation in the more refrangible regions is to give an apparent dilution to them, while the less refrangible regions are concentrated.

Accordingly, in May, 1843, Dr. Draper succeeded in inducing Joseph Saxton, the eminent mechanician of the United States mint at Philadelphia, to rule for him a diffraction grating. With this grating, which was of glass and five-eighths of an inch by one-third of an inch in size, the diffraction spectrum was produced and the above difficulties avoided. Dr. Draper effected a great improvement in the grating by silvering its ruled surface with tin amalgam, thus producing a reflected spectrum which was far more brilliant than the transmitted one, though he suggested that perhaps it would be better to rule them originally on steel or speculum metal. It 
was at this time, too, that Dr. Draper suggested that the different regions of the spectrum should be indicated by their wave-lengths. "Since the deviations of the different fixed lines, B, C, D, in the interference spectrum," he says, "are proportional to the lengths of the undulations which they respectively represent, by designating the different points of the spectrum by their wave-lengths, the subdivision may be carried to any degree of minuteness ; the measures of one author will compare with those of another and the different phenomena of chemical changes occurring through the agency of light become allied at once with a multitude of other optical results."

It was with this grating that the diffraction spectrum was for the first time photographed. A daguerreotype plate, rendered sensitive by iodine and then by bromine, and exposed for half an hour, gave a maximum sensitiveness at wave-length 0.00001538 Paris inch. A plate prepared by iodine, bromine, and chloride of iodine, and exposed for an hour, gave a niaximum at the same point, the decomposition extending from wave-length 0.00002007 in the green to 0.00001257 in the violet. In these photographs the fixed lines were beautifully distinct.

Dr. Draper, too, was among the first to point out the unsatisfactory character of the measurements which have been made with the prismatic spectrum on the distribution of heat. Since the less refrangible regions are much compressed and the more refrangible much dilated, the measures obtained by means of a uniform movement through the spectrum cannot be accepted as expressing the true distribution. Hence, in 1857, he attempted to determine the curve of distribution in a diffraction spectrum; but the results, though suggestive, were not conclusive. Subsequently, in 1872, he devised a simple modification of the prismatic spectrum method, which accomplished practically the result which he had desired to obtain with the interference spectrum. Using Angström's values expressed in ten millionths of a millimeter, the wave length of the line $\mathrm{A}$ is 7,604 and that of $\mathrm{H}_{2} 3,933$, these lines bounding very nearly the visible spectrum. The middle point is, therefore, at 5,768. If, now, the heat be determined first in the region from 7,604 to 5,768 , and then from 5,768 to 3,933, may not the question of its uniform distribution be thus settled? Upon making the experiment it was found that the two halves of the spectrum gave identically the same amount of heat, and this whatever be the material of the prisms. 
Hence it follows that any two series of undulations in the spectrum will have the same heating power, no matter what their wavelengths may be.

Continuing his spectrum investigations, Dr. Draper next sought to determine the law of the distribution of light. Mosotti, in Italy, had already studied the diffraction spectrum, and had shown that the maximum of illuminating power lay in the yellow, the intensity declining symmetrically on either side. The photometric method of Bouguer Dr. Draper had used in 1847, with good results, to measure the intensity of the light radiated from incandescing platinum; and he now, in 1879, sought to construct a spectrometer on the same principle which should measure light-intensity. The principle is a well-recognized one in optics. It is that any light becomes invisible in presence of another light sixty-four times as strong. If, as Mosotti had maintained, the yellow be the brightest of the spectrum colors, then in presence of an extraneous light thrown on the spectrum and variable at will, the yellow will remain after the red and orange on the one side, and the green, blue, and violet on the other, have been extinguished. But on making the experiment, throwing the extinguishing white light through the third telescope of an ordinary spectroscope, so as to reflect it to the eye from the face of the prism, Dr. Draper found that the colors of a gas-flame spectrum disappeared in the inverse order of their refrangibility, the red-being the last to disappear. Analogous experiments with the spectrum of sunlight, which was sometimes thrown on a screen and sometimes on the ground glass of a camera and extinguished by daylight, gave precisely similar results. On gradually opening the shutter admitting the daylight, the extreme violet disappeared first, and then the other colors in the inverse order of refrangibility as before. On closing the shutter the red first came into view, and then the other colors successively. Obviously, if this result is due to the compression at the red end of the prismatic spectrum, then it should not be found in that produced by diffraction; and on making the experiment Dr. Draper saw, not without pleasure, that as the intensity of the extinguishing beam increased all the colored spaces yielded apparently in an equal manner and disappeared at the same moment. On diminishing the intensity of the extraneous light he observed that they all came into view apparently at the same time. The yellow, as before, showed no superiority over the other colurs in resisting extinction. It would seem, therefore, that 
the apparent brightness of the yellow, as seen by the eye, is a purely physiological phenomenon.

Another subject to which Dr. Draper devoted a large share of attention was phosphorescence. In his first memoir on this subject, published in 1851, he discusses the general character of the phenomenon, and restricts the term phosphorescent to those bodies which shine in the dark after exposure to light or on being heated. Fluorspar, of the variety known as chlorophane, which yields a superb emerald-green light, was selected for experiment. He found that when made to phosphoresce by the electric spark it underwent neither expansion nor contraction, nor any other molecular change detectable in polarized light. He did observe a minute evolution of heat, but could detect no electrical change. Nor did the presence of a powerful magnetic field appear to affect the result. On measuring the amount of light emitted it appeared that this splendid green light was photographically twenty-four times, and photometrically three theusand times, less intense than that of the small flame of an oil lamp taken for comparison. But he noticed that the quantity of light emitted by a phosphorescent body was proportional to the intensity of the light to which it had been exposed. In 1844 Dr. Draper determined that the special phosphorogenic rays of the spectrum were the violet rays. In this research he used a quartz train and threw the spectrum upon a screen covered with calcium sulphide. He observed, further, that for the transient light of the spark quartz is transparent but glass is opaque-that is, so far as a surface of calcium sulphide is concerned, though not a sensitive silver surface. Moreover, while glass is opaque to phosphorogenic rays from the spark, it transmits freely those from incandescent lime, so that the calcium light, the light of an oil lamp, and sunlight can excite phosphorescence through glass; that of the electric spark or of the voltaic discharge in mercury cannot. If, however, the latter be continuous an effect is produced even through glass.

In his last scientific memoir, published near the close of 1880 , Dr. Draper called attention to the striking resemblance existing between a photograph of the solar spectrum taken on silver iodide and a phosphorograph taken on luminous paint. 'The former, when taken in presence of a weak extraneous light, shows the three regions which were pointed out by him in 1842: (1), a middle region, extending from the boundary of the green and blue to a little beyond the violet; lere the silver iodide is blackened; (2), below this 
and extending from the green to the ultra-red is a strongly-marked region in which the action of daylight has been altogether arrested or removed, the daylight and the sunlight having apparently counterbalanced and checked one another ; and (3), a similarly protected region, much shorter, beyond the violet. The phosphorograph, in the absence of extraneous light, shows a shining region corresponding to number one of the photograph. But if foreign light intervenes there is annexed to this region another, including the less refrangible spaces, of decided blackness, broken, however, at a short distance below the red by a luminous rectangle of considerable width, formed by the coalescence of the bands $\alpha, \beta, \gamma$. There is also a similar but smaller region in the violet. In this memoir Dr. Draper notices the rapidity with which the red spectrum rays extinguish phosphorescence.

The electrical investigations which were undertaken by Professor Draper were much fewer in number than those on light. One of the most important of these was a paper on the electromotive power of heat, published in 1840, in which he discusses the electromotive force developed in pairs of different metals as the temperature rises and gives values for wires of copper-iron, silver-palladium, ironpalladium, platinum-copper, iron-silver, and iron-platinum, obtained with one junction kept at $32^{\circ}$ and the other raised either to $212^{\circ}$ or to $662^{\circ} \mathrm{F}$. He gives curves of the thermo-electric action of these metals, the abscissas being temperatures and the electromotive forces ordinates, constituting a thermo-electric diagram. In this diagram the curves of iron-palladium and copper-silver are concave toward the axis of abscissas, while those of iron-platinum, copper-platinum, and silver-palladium are convex toward this axis. $\mathrm{He}$ observed also that the increase of electromotive force with temperature diffored for the different pairs. He calls attention to the anomalous results which are given by pairs into which iron enters, and gives the diagram of a copper-iron couple, the maximum ordinate of which is at $650^{\circ}$ and the neutral point at a temperature at which an alloy of equal parts of brass and silver melts. The paper concludes with several suggestions in regard to the forms which it is desirable to give to the components of a thermo-electric couple.

In 1834 he studied the action of the galvanic battery and published an account of some improvements in its construction which his experiments had suggested. In 1835 he repeated the experiments of Morichini and Mrs. Somerville on the reputed magnetiz- 
ing effect of violet light, and came to the conclusion that there was no evidence whatever to sustain the opinions of these experimenters. In 1839 he published a somewhat extended paper on the use of a secondary wire as a measure of the relative tension of electric currents, describing the construction and use of a torsion galvanometer and discussing a method of measuring electro-motive force by the fall in the deflection when a wire of high resistance was included in the circuit. He also considers in this paper the relations of electro-motive force and of resistance to the current produced. In 1843 a paper on the law of the conducting power of wires gave the results of his measurements made to solve the problem of transmitting electric impulses through long lengths of a eonductor, a research undertaken to aid his colleague, Professor Morse, in perfecting his electro-magnetic telegraph. In this paper the author shows that the diminution of the strength of an electric current itself diminishes rapidly with increase of length in the wire, and that generally the conducting effect of wires may be represented by a logarithmic curve.

The purely chemical researches published by Dr. Draper were also few in number. Among these may be mentioned his ' memoirs on the analysis of certain ancient coins and medals (which seemed to him to prove the possibility of diffusion in solids) on micro-chemistry, on the constitution of the atmosphere, on respiration, on the allotropism of chlorine, on the existence and effects of allotropism in the constituent elements of living beings, on a singular property of gun-cotton mixture, and on a new method for the determination of urea.

In 1844 , in a volume on the forees which produce the organization of plants, Dr. Draper published, as an appendix, the scientific memoirs of his which had appeared up to that time bearing on this question, and in 1873, in a book entitled "Scientific Memoirs," he collected together the papers which he had published upon Radiant Energy and closely allied subjects.

During the later years of his life Professor Draper devoted his time much more largely to literary than to scientific work. Upon his appointment to the chair of physiology in 1850 he turned his attention once more to physiological subjects, and in 1856 he collected together the matter which he had carefully elaborated in his class lectures into his "Human Physiology, Statical and Dynamical." This book marked a new departure in the science of physiology, 
since it contained not only the results of his valuable original investigations on various important subjects, illustrated by his own admirable micro-photographs, but also clear and forcible discussions of the applications of strictly scientific theory to a region heretofore almost entirely given over to a hypothetical vital force. "Among the new experiments and explorations which it contained may be mentioned the condensing action of membranes, the cause of the coagulation of the blood, the theory of the circulation of the blood, the explanation of the flow of sap, the endosmotic action of thin films, the measure of the force of endosmose, the respiration of fishes, the action of the organic muscle-fibers of the lungs, the allotropism of living systems, the action of the skin, the functions of the nerve vesicles and their electrical analogies, the functions of the sympathetic nerve, the explanation of certain parts of the auditory apparatus, particularly of the cochlea and semicircular canals, the theory of vision, and the theory of muscular contraction." This treatise took at once a recognized rank as a text-book, both in this and other countries, and was translated into several foreign languages, and even into Russian.

Perhaps it was quite natural that a philosophic mind like Draper's should be led by these studies to formulate a sort of socialistic physiology and to trace in the working of communities and nations the same laws which control the evolution of the individual. But however this may be the "Physiology" was followed, in the course of a few years, by what many have considerer his most brilliant work, "A History of the Intellectual Development of Europe," published in 1863. "The object of this work was mainly to point out that the intellectual progress of nations proceeds in the same course as the intellectual development of the individual ; that the movement of both is not fortuitous, but under the dominion of law; that the stages of personal development are paralleled by the stages of social development, and, indeed, as paleontology has proved, by the evolution of all animated nature, and that there is an ascent of man through well-marked epochs from the most barbarous to the most highly civilized condition." In short it was designed to be an argument in favor of evolution and the reign of law in the historical development of the world. Few philosophical works have attained to celebrity so quickly. It ran rapidly through many editions in this country and was translated into nearly every European language. The Westminster Review said of it: "It is one of the not 
least remarkable achievements in the progress of positive philosophy that has yet been made in the English tongue-a noble and even magnificent attempt to frame an induction of all the recorded phenomena of European, Asiatic, and North African history. Unaccustomed though a reader might be to scientific habits of thought or uninterested in the gradual elaboration of eternal rules and principles, here he can at least disport himself anid noble galleries of historic paintings and thrill again at the visions of the touching epochs that go to forn the drama of the mighty European past. What Comte showed might and ought to be done for the whole world of man; what Buckle commerced for England, Scotland, France and Spain, Draper has effected for the whole of Europe. The gigantic vastness of the task is almost paralyzing." So too the Athenoum: "It is no light commendation to say that its execution is not altogether unequal to its magnitude. If it were equal the world would place Dr. Draper on one of the very highest pinnacles of intellectual achievements. His tenacity and completeness of grasp makes itself felt for the most part on every page."

In 1864 the Historical Society of New York invited Dr. Draper to deliver a course of four lectures upon some subject in general political economy. These lectures were afterward expanded and published the following year under the title, "Thoughts on the Future Civil Policy of America." They treated : (1) on the influence of climate upon man; (2) on the effects of emigration; (3) on the political force of ideas, and (4) on the natural course of national development. These lectures "contained discussions of several interesting points which since that time have largely occupied public attention, such as the internal emigration from the Atlantic States to the West, the Asiatic emigration to the Pacific States, the political effects of polygamy in Utah, the tendency of democratic institutions to centralization, and a comparison of the European with the American method of government."

The line of investigation thus entered upon resulted in his undertaking a far more serious labor, the preparation of a "History of the American Civil War," a work upon which he was almost continuously engaged for several years immediately following the close of this war, and which appeared in three large volumes during the years between 1867 and 1870 . He had been urged to enter upon this work by the earnest request of persons who had been chief actors in the events described and who rendered him effective aid. 
Mr. Stanton, the Secretary of War, issued orders to the adjutant general of the army of the United States to "furnish him copies of all orders, reports, correspondence, telegraphic dispatches, or other documents on file in the War Department as he might request, and to permit him to inspect and have copies of any maps, plans, and other papers necessary for the preparation of his work, and to furnish him with statistical information respecting the armies of the United States, their organization and operations." This order ineluded also all the Confederate archives in possession of the War Department. Nor was the interest of the Secretary of War limited to this. He supplied a large amount of personal information of the utmost value. Access was not unfrequently given the author to documents and correspondence of the most confidential kind, with a view of guiding him to correct conclusions; and many of the most decisive military operations are detailed from private memoranda furnished by the commanding officers themselves.

The last literary work on which Dr. Draper was engaged was the "History of the Conflict between Religion and Science,". issued in 1874 as one of the volumes of the International Scientific series. Much of the material utilized in this volume is said to have been matter originally intended for the "Intellectual Development of Europe." The book attempted to trace the development of the antagonism which has ever been present between the conservative and the scientific elements of thought, between the ecclesiastical and old on the one side and the radical and new on the other. The former, al ways opposed to the progress of the latter, has sought in all times to hinder this progress by every means it could devise lest forsooth some of its antiquated tenets should require modification. The title of the book has sometimes been criticised on the ground that religion is a personal element entirely, and with this, of course, science can never be in antagonism. But using the word in the broader sense, in which Dr. Draper used it-as synonymous with ecclesiasticism and theology - there always has been a conflict between them and there always will be so long as they both shall exist. The favor with which this book was received was something surprising. In the first ten years of its existence it passed through more than twenty editions in the Euglish language and was translated into French, Spanish, German, Dutch, Russian, Italian, Portuguese, Polish, and Servian. It has even been placed on the Index Expurgatorius of the Romish church, an honor which its author has 
shared with Galileo, with Copernicus, with Kepler, with Locke, and with Mill.

In all his literary work Dr. Draper's methods were always of the same high character as those which distinguished his scientific investigations. He showed alike in both the same close and impartial scrutiny of the facts, the same careful and minute examination of all the conditions which they involved, the same conscientious and exact record of the results obtained. After passing the ordeal of his severe criticism his work had little to fear from outside attack. All that he did was pervaded by the high moral tone which characterized the man. If he was scrupulously accurate in observing and testing his facts and in drawing inferences from them, if he was ingenious in devising and skillful in applying crucial tests to detect error or misconception, he was equally honest in placing his observations and conclusions on record and in according to his contemporaries and co-workers the full share of praise to which they were entitled.

It is not easy to estimate the value of Dr. Draper's services as a teacher. From the time of his appointment to the professorship in Hampden Sidney College in 1836 until the year before his deatha period of forty-five years-he was constantly occupied in the work of instruction. Of the facilities at his disposal when he first went to New York he thus speaks : "Our laboratory was then in a little dark back room without ventilation. The morning sun struggled almost in vain to see what we were doing, for the windowpanes were covered with an incongruous arrangement of Venetian blinds and Gothic mullions. A hole in the ceiling led up to the chapel above, to the pulpit of which the material for the daily lecture was carried in a tea-tray. I called it a pulpit, because they used to preach out of it. A clergyman, who also statedly occupied it, regarded it as a pneumatic trough, because I experimented in it. And this, I think, it really was, for, recalling the Greek etymology of that epithet, it plainly indicates the double function, spiritual as well as chemical. Our laboratory work commenced at seven in the morning and contisued uninterruptedly till after midnight, and, as might have been readily foreseen, what, with the impure air and mental application, the individual chiefly engaged twice contracted a fever and narrowly escaped with his life." Dnring the ten years from 1840 to 1850 he gave a series of introductory lectures to the medical classes in the university, which are among the best popular 
expositions of the applications of science to medicine to be found in the language. These, as well as his valedictory lectures, were generally printed by the classes to which they were severally addressed. According to competent authority they were "clear in statement, fresh and striking in their views, and lively, poetic, and witty, as well as instructive, well fitted to awaken the students' enthusiasm." Those on the relations of chemistry to medicine, on the history of chemistry, on atmospheric air, on water, on oxygen, and on phosphorus are spoken of as having been exceptionally suggestive and brilliant.

Dr. Draper appeared but rarely upon the platform of the public lecturer. In 1853 he made an address before the Alumni Association upon "The Indebtedness of the City of New York to its University," which was a strong plea for science in education. In 1863 he gave the anniversary discourse before the New York Academy of Medicine, the subject of which was "The Historical Influence of the Medical Profession." His lectures before the Historical Society in 1864 have already been mentioned. As president he addressed the American Union Academy at its first annual meeting in 1870. His felicitous address at the farewell dinner to Professor Tyndall, given in New York in February, 1873, and his inaugural address as president of the American Chemical Society on "Science in America," delivered in 1876, are among his happiest efforts. One of the most noteworthy of his public addresses was that upon Evolution, delivered before the Unitarian Institute, in Springfield, in October, 1877.

Besides the work which Dr. Draper did in pure science he was closely connected with the development of two of the most important inventions ever made. One of these was the electro-magnetic telegraph of Morse, the other was the art of photography. In one of his addresses to the alumni (1853) he gives the following account of the evolution of the telegraph: "Fourteen years ago there stood upon the floor of the chemical laboratory of our University a pair of old-fashioned galvanic batteries. Like the cradle of a baby, they worked upon rockers, that so the acid might be turned on or off. A gray-haired gentleman had been using them for many years to see whether he could produce enough magnetism in a piece of iron at a distance, to move a pencil and make marks upon paper. He had contrived a brass instrument that had keys something like a piano in miniature, only there was engraven on each a letter of the 
alphabet. When these were touched the influence of the batteries was sent through a copper wire and a mark answering to a letter was made a long way off. * * * But long after the telegraphic instruments were perfected it was doubtful whether intelligence could be sent to any considerable distance. It is one thing to send an electric current a few yards and a totally different affair to send it a thousand miles. Experiments which had been made under the auspices of the Russion government by Professor Jacobi, of the University of Dorpat, had led to the inference that the law of the conducting power of wires, originally discovered in Germany, was correct; and, in addition, a corroborative memoir had been read by Lenz before the Imperial Academy of Sciences at St. Petersburg. At this time so little was known in England as regards this important point, that some of the most eminent natural philosophers connected with universities there embraced the opposite view. I may not be able to make the precise point in dispute clear; it was this: A current passing through a certain length of wire suffers a certain amount of loss. If it should go through a wire a thousand times as long will the loss be a thousand times as great? The Russians said yes; the English said no. If the former was the case it was universally concluded that the electric telegraph would not be practicable for any considerable distance. A series of experiments was made in the University of New York which established beyond all question the truth of the Russian view. But at that time the higher mathematics were cultivated in our laboratory, as well as mere experimenting; and on submitting the results to such a mathematical discussion the paradoxical conclusion was brought out that it is a necessary consequence of that law that after a certain length of wire has been used the losses become imperceptible. Encouraged by this, a party of gentlemen went with the inventor of the telegraph to a rope-walk near Bloomingdale, one summer morning, and there tested the truth of these conclusions on lengths of wire varying from one to some hundreds of miles. The losses of the currents were measured by the quantity of gas set free in the decomposition of water. The result was completely successful, and telegraphing for any distance became an established certainty."

The part which he took in the evolution of photography he thus describes: "When the French government, in 1839, purchased of Daguerre his invention of photogenic drawing, its applications were very limited. The process was adapted to interiors, statuary, and 
architectural subjects, but wholly unsuited to landscape scenery or to portraits. The inventor himself had made attempts at applying it to the taking of likenesses, but had given it up in despair. Soon after the publication of Daguerre's invention in America a series of experiments was conducted in our laboratory with a view of determining whether the difficulties could be removed." The results were successful, and the taking of portraits from life by daguerreotype became before long an everyday operation.

The great value of Dr. Draper's contributions to science has been cordially recognized by the highest authorities. Melloni, the creator, as it were, of the science of radiant heat, warmly congratulated him on his memoir on this subject, presented an abstract of it to the Royal Academy of Sciences at Naples, and in his own subsequent memoir warmly commends the ingenuity and ability of the American scientist. Herschel was equally cordial in praise of his photochemical researches. Berzelius, a few days before his death, sent to Dr. Draper his portrait with a kind message conveying his appreciation of what he had done for science. Kirchhoff, in 1862, thus speaks of his heat experiments: "Draper has derived from experiment the conclusion that all solid bodies begin to glow at the same temperature, but he has observed in his experiments that certain bodies, as chalk, marble, and fluor-spar, shine at a lower temperature than they should according to this law; he calls this light phosphorescent and observes that it is distinguished from the glow by its color. But whatever name may be given to the light it contradicts the law, and a body which shows it cannot satisfy the assumption which is made in proving the law; it cannot remain unchanged, the temperature remaining the same; the phosphoresence is not the simple influence of heat, it is not exclusively conditioned on temperature, but it is caused by changes in the body; if these changes, be they chemical or of any other kind, cease, then the phosphoresence must also vanish." Bunsen and Roscoe have recognized Dr. Draper most fully as the pioneer in the investigation of the action of light upon chlorine, a subject worked out successfully by them.

Dr. Draper was elected a member of many of the learned societies of Europe, among them the Accademia dei Lincei, at Rome, and the Physical Society of London. In 1843 he was elected a member of the American Philosophical Society at Philadelphia, and in 1860 he received the degree of LL. D. from the college of New 
Jersey at Princeton. In 1875 the American Academy of $\Lambda$ rts and Sciences at Boston awarded to him the Rumford medals for his reseaches on Radiant Energy. In his speech of presentation the Hon. Charles Francis Adams, then president of the Academy, after recapitulating the reasons given by the committee for recommending this award, said to Mr. Quincy, who was deputed in Dr. Draper's absence to receive the medals: "I pray you, in receiving these two medals on his behalf, in accordance with the terms of the original trust, to assure him on the part of the Academy of the high satisfaction taken by all its Fellows in doing honor to those who, like him, take a prominent rank in the advance of science throughout the world." In his letter of reply Dr. Draper says: "Your favorable appreciation of my researches on radiation, expressed today by the award of the Rumford medals - the highest testimonial of approbation that American science has to bestow on those who have devoted themselves to the enlargement of knowledge-is to me a most acceptable return for the attention I have given to that subject through a period of more than forty years. * * * It adds impressively to the honor you have this day day conferred on me that your action is the deliberate determination of competent, severe, impartial judges. I cannot adequately express my feelings of gratitude in such a presence, publicly pronouncing its approval of what I have done."

Professor Draper was not elected a member of the National Academy of Sciences until 1877. It is not easy to understand at this late day why a man so eminent in science was not included among the original incorporators of the Academy. An attempt, it is believed, was made to remedy this apparent oversight during the meeting which was held in New York in 1863 for organization, but for some unexplained reason the effort failed. So uncalled for an action on the part of the Academy rendered il for some time doubtful whether he would accept the mernbership when it was subsequently tendered.

Dr. Draper was married at quite an early age. While a student at the University of London in the year 1830 , then nineteen years old, he boarded with a friend of his father's, Mrs. Barker by name, where he met her niece, Miss Antonia Gardner, who was then residing with her and attending a young ladies' school in the neighborhood. This young lady was the daughter of Dr. Gardner, of Rio Janeiro, the attending physician of the Emperor of Brazil, 
Dom Pedro I. Though himself an Englishman Dr. Gardner had married into the celebrated de Piva-Pereira family of Portugal, and this, their only daughter, had been brought to London to complete her education. Within a few months they became engaged, and in 1831, not long after the death of her father, in Brazil, they were married. In 1832 Dr. Draper's father also died, and his mother accompanied the newly-married couple across the ocean to settle among the little Wesleyan colony in Virginia, where she died in the following year. It was to his accomplished wife that Dr. Draper owed much of the happiness which characterized his married life. Six children were born to them, one of whom died in infancy. The eldest son, John Christopher Draper, was born in Virginia in 1835 and became his father's successor as professor of chemistry in the medical department of the University of New York. He died on the 20th of December, 1885. The second son, Henry Draper, was born in 1837 also in Virginia. He became professor of physiology in the university and subsequently professor of analytical chemistry. He early turned his attention in the direction of physical research, especially in its application to astronomy, and wạs elected a member of the National Academy in 1877. His early death in 1882 alone prevented his rising to an equal eminence as an investigator with that attained by his distinguished father. The third son, Daniel Draper, is at present the director of the Meteorological Observatory in Central Park, New York. Dr. Draper's daughters were Virginia, afterward Mrs. Maury, named for the State in which she was born, who died in October, 1885, leaving three children; and Antonia, who is at present Mrs. Edward H. Dixon.

Any record of the Draper family, however, which did not mention Dr. Draper's elder sister Catherine would be quite incomplete. As already mentioned, she accompanied the newly-married couple across the ocean when they removed to America. Having shared her brother's tastes for scientific studies, she became his assistant in research and rendered him most valuable aid. Her portrait was the first ever taken from the life by the daguerreotype process, and the colored plates which illustrate his memoirs were the work of her pencil. She was a constant inmate in his family, and during the many years of Mrs. Draper's ill health she was as a mother to the children. She has outlived her brother, and resides still at the fanily mansion in Hastings. 
On coming to New York Dr. Draper occupied at first a house in Charles street, subsequently removing to the corner of Broadway and Amity street. But in 1848 he purchased a delightfully located piece of property at Hastings upon the Hudson, where he lived until his death. It was here that Henry Draper built his observatory; and in this building the father and son spent many a pleasant hour together engaged in that most delightful of occupations, the pursuit of scientific knowledge.

Dr. Draper, thougk somewhat below the average stature, was a man of fine personal presence. He was mild in manner and quiet in demeanor, having very little of self-assertion. The excellence of his disposition and the charm of his personal intercourse drew to him warm and disinterested friends on every hand. He was an extensive reader and his conversational powers were remarkably developed, so that he always had attentive listeners, whether the subject of his discourse was literary or scientific. But it was when he opened his rich storehouse of personal reminiscence that his auditor was most charmed and delighted. His health, which through life had been generally good, was disturbed during his later years by severe attacks of gravel, which incapacitated him for journeying. These attacks wore upon him and finally ended his life. He died at Hastings, on the 4th of January, 1882, and was buried at Greenwood.

In the eloquent words of Professor Lovering, "Dr. Draper's mind was too large to be shut up within the walls of his laboratory. To him the minutest facts were of value, but only as they furnished the key for interpreting the Universal Cosmos of nature and humanity. In clear and graceful language the best that was in his thoughts was shared by the world. There was a continuity in his life-work, plain to himself, if not obvious to the superficial observer. He says : 'When I thus look back on the subjects that have occupied my attention I recognize how they have been interconnected, each preparing the way for its successor. Is it not true that for every person the course of life is along the line of least resistance, and that in this the movement of humanity is like the movement of material bodies?", 


\section{PUBLICATIONS OF JOHN WILLIAM DRAPER.}

\section{I.-SCIENTIFIC MEMOIRS.}

1832.

On voleanoes. By W. M. Higgins and J. W. Draper. Mag. Nat. Hist., v, 164-174, 262-272, 632-637 ; vi, 344-350, 1832.

liemarks on the formation of the Dead Sea and the surrounding district. By W. M. Higgins and J. W. Draper. Mag. Nat. Hist., v, 532-534, 1832.

\section{3.}

Remarks on electrical decompositions. By William M. Higgins, F. G. S., and J. W. Draper (dated 110 Chancery Lane, August, 1832). Edinb. New Phil. Journ., xiv, 314-317, A pril, 1833.

\section{4.}

Influence of electricity on capilary attraction. (Extract of a letter from Jno. W. Draper to the editor, dated Christiansville, Mecklenburg, Va., May 31st, 1832*.) Am. J. Sci., I, xxvi, 399, July, 1834.

Some experimental researches to determine the nature of capillary attraction. J. Fr. Inst., xiv, 147-165, September, 1834.

An account of some experiments made to determine the best construction of galvanic batteries of four elements. J. Fr. Inst., xiv, 289-295, November, 1834 .

Chemical analysis of native chloride of carbon. J. Fr. Inst., xiv, 295-298, November, 1834.

\section{5.}

Experiments to determine whether light exerts magnetic action. $J . \mathrm{Fr}$. Inst., xv, 79-85, 155-158, February, March, 1835.

Idolatry and philosophy of the Zabians. Am. J. Sci., I, xxviii, 201, July, 1835.

On the chemical analysis of coins and medals. Am. J. Sci., xxix, 157-166, October, 1835. (Bibliotheque Universelle 1835, 370-374. Froriep Notizen, $\mathrm{xlix}, 7-9$.)

1836.

On the tidal motions of conductors free to move. J. Fr. Inst., xvii, 27-33, January, 1836.

Experiments on absorption. Am. J. Med. Sci., xviii, 13-32, May, 1836.

Experiments on endusmosis. J. Fr. Inst., xvii, 177-182; xviii, 27-31, March, July, 1836. (Phil. Mag., III, xi, 559, December, 1837.)

Observations on microscopic chemistry. J. Fr Inst., xviii, 378, December, 1836.

* 'This must be a misprint for $183 \mathrm{H}$, since at this date, in 1832 , Draper had not yet left England. 


\section{NATIONAL ACADEMY OF SCIENCES.}

1837.

Experiments on solar light. Am. J Med. Sci., xx, 268, May, $1837 ; J$. Fr. Inst., xix, 469-479, June ; xx, 38-46, July ; 114-121, August : 250-255, October, 1887. (Sturgeon's Ann. Elec., ii, 397-399, 1838.)

Remarks on the action of presence. Am. J. Merl. Sci., xxi, 123-136, November, 1837. (Froriep Notzzen, II, v, 257-250, 1839.)

\section{8.}

Simultaneous meteorologieal observations. J. Fr. Inst., xxi, 39, January, 1838 .

On the physical action of enpillary systems. Identification of the force produeing motion with the ehemical force (dated November 20, 1837). Am. J. Med. Sci., xxi, 289-302, February, 1838.

Oil some mechanical functions of areolar tissues. Containing the co-ordination of the diffusion laws of Professor Grabam and the experiments of Dr. J. K. Mitchell and the general laws of equilibrium. Am. J. Med. Sci., xxii, 23-44, May ; 302-323, August, 1838.

Remarks on the constitution of the atmosphere. Phil. May., III, xxii, 241-252, Oetober, 1838.

1839.

Further remarks on the action of presence. Am. J. Med. Sci, xxiii, 68-81, September, 1839.

On the use of a secondary wire as a measure of the relative tension of electric currents. Phil. Mag., III, xv, 266-279, October; 339-349, November, 1839. (Bibliotheque Universelle, xxiv, 176-179, 1840.)

\section{0 .}

An account of some experiments made in the south of Virginia on the light of the sull. Phil. Mag., III, xvi, 81-84, February, 1840. (Froriep) Notizen, II, xiii, 337-341.)

On the electromotive power of heat. Phil. May., III, xvi, 451-461, June, 1840.

On the process of daguerrentype and its application to taking portraits from the life. Phil. Mag, III, xvi, 535, June; xvii, 217, September, 1840. (Sturgeon's Ann. Elec., vi, 503-504.)

\section{1.}

On some analogies between the phenomena of the chemical rays and those of radiant heat. Phil. Mag., III., xix, 195-210, September, 1841.

1842 .

On certain spectral appearances and on the discovery of latent light. Phil. Mag., III, xxi, 348-350, November, 1842. Am. J. Sci., I, xliv, 202, October-December, 1842 .

On a new imponderable substance und on a class of ehemical ruys analogous to the rays of dark heat. Phil. Mag., III, xxi, 453-461, December, 1842. (Froriep Notizen, II, xxv, 1-8, 17-23, 1843.) 


\section{JOHN WILLIAM DRAPER.}

1843.

On the rapid detithonizing power of certain gases and vapors, and on an instantaneous means of producing spectral appearances. Phil. Mag., III, xxii, 161-165, Mareh, 1843. (Sturgeon's Ann. Elec., x, 462-465. Froriep Notizen, II, xxv, 340-343, 1843.)

On a new system of inactive tithonographic spaces in the solar spectrum analogous to the fixed lines of Fraunhofer. Phil. Mag., III, xxii, 360-364, May, 1843.

On the tithonotype, or art of multiplying daguerreotypes. Phil. Mag., III, xxii, 365, May, 1843.

On the decomposition of carbonic-acid gas and the alkaline carbonates by the light of the sun, and on the tithonotype. Proc. Am. Phil. Soc., iii, 111114, May, 1843. Phil. May., III, xxiii, 161-176, September, 1843. (Rep). Brit. Assoc., 1843, Pt. 2, 33-34; Chemist, 1843, iv, 444-445; An. J. Sci., I, xlvi, 398, 1844; Ann. Chim. Phys., xi, 214-228, 1844; J. Pr. Chem., xxxi, 21-39, 1844; Napoli Rendi Conto, iii, 297-306, 1844.)

On the law of the conducting power of wires. Am. J. Sci., I, xlv, 392, .July-September, 1843 (Archiv. de l'Elec., vi, 329-330, 1844).

On a change produced by exposure to the beams of the sun in the properties. of an elementary substance. Rep. Brit. Assoc., 1843, Pt. 2, 9. Phil. Mag., III, xxiii, 388, November, 1843. (Chemist, iv, 442-443, 1843; Am. J. Sci., I, xlvi, 390, January-Mareh, 1844.)

Description of the tithonometer [chlorhydrogen photometer]; an instrument for measuring the chemical force of the indigo-tithonic rays. Phil. Mag., III, xxiii, 401-405, December, 1843; Am. J. Sci., I, xlvi, 217-232, January-IIarch, 1844.

1844

On Mr. Hunt's book entitled "Researches on Light." Phil. Mag., III, $\mathrm{xxv}, 49$, July, 1844.

On tithonized ehlorine. (Read at the meeting of the British Association in Cork in 1843.) Phil. Mag., III, xxv, 1-10, July, 1844.

Further considerations on the existence of a fourth imponderable. Phil. Mag., III, xxv, 103-116, August, 1844.

Note on the decomposition of carbonic acid by the leaves of plants under the influence of yellow light. Phil. Mag., III, xxv, 169-173, September, 1844 .

1845 .

Is capillary action an electrical phenomenon? Phil. Mag., III, xxvi, 185-189, March, 1845.

On the interference spectrum and the absorption of the tithonic rays. P'hil. Mag., III, xxvi, 465-478, June, 1845.

On the allotropism of chlorine as connected with the theory of substitutions. Am. J. Sci., I, xlix, 346-368, July-Suptember, 1845. Phil. Mag., III, xxvii, 327-346, November, 1845. (Bibl. Universelle, lx, 365-379, 1845; J. Pr. Chem., xxxvii, 103-109, 1846 ; J. Pharm., ix, 398-399, 1846.) 


\section{NATIONAL ACADEMY OF SCIENCES.}

Account of a remarkable difference between the rays of incandescent lime and those emitted by an electric spark. Phil. Mag., III, xxvii, 435-437, December, 1845.

1846.

On the eause of the eirculation of the blood. Phil. Mag., III, xxviii, 178-189, March, 1846; Am. J. Sci., II, ii, 276-279, September, 1846. (Froriep Notizen, II, xxxvii, 289-296, 305-311.)

\section{7.}

Remarks on the existerce and mechanism of the protecting or negative rays of the sun. Phl. Mag., III, xxx, 87-93, February, 1847. (Bibliotheque Universelle, v, 5-14, 1847 ; J. de Pharm., xii, 152-154, 1847.)

Singular property of gun-cotton mixture. Phil. Mag., III, xxx, 299, A pril, 1847.

On the production of light by heat. Phil. Mag., III, xxx, 345-360, May, 1847 ; Am. J. Sci., II, iv, 388-402, November, 1847. (Froriep Notizen, III, iv, $97-102,113-119,1847$.)

\section{8.}

On the production of light by chemical action. Phil. Mag., III, xxxii, . 100-114, February, 1848; Am. J. Sci., II, v, 159-172, March, 1848. (Froriep Notizen, III, vii, 17-24, 33-37, 1848.)

1849.

On the existence and effects of allotropism in the constituent elements of living beings. Phil. Mag., III, xxxiv, 241-246, A pril, 1849.

1851.

On the phosphoreseence of bodies. Phil. Mag., IV, i, 81-100, February, 1851.

On the chenical action of light. Phil. Mag., IV, i, 368-393, May, 1851. (J. de Pharm., xx, 253-258, 1851.)

1852.

On respiration. Am. J. Med. Sci., II, xxiii, 314-320, January, 1852.

1853.

On a new method for the determination of urea. Phil. May., IV, vi, 290292, Oetober, 1853.

1857.

On the diffraction spectrum. Phil. May., IV, xiii, 153-156, March, 1857.

On the measurement of the chemical action of light. Phil. Mag., IV, xiv, 161-164, September, 1857. (J. Phot. Soc., iv, 34-36, 1858.)

On the influence of light upon ehlorine and some remarks on alchemy. Phil. Mag., IV, xiv, 321, November, 1857.

\section{8.}

(n) the nature of flame and on the condition of the sun's surface. Phil. Mag., IV, xv, 90-93, February, 1858; Am. J. Sci., II, xxvi, 268-271, September, 1858. 


\section{JOHN WIILIAM DRAPER.}

1863.

On the motions of eamphor toward the light. Phil. Mag., IV, xxv, 38, January, 1863.

On the motions of eamphor toward the light and on variations in the fixed lines of the solar spectrum. Phil. Mag., IV, xxv, 342-344, Mny, 1863.

1872 .

Researches in actino-chemistry. Memoir first. On the distribution of heat in the spectrum. Phil. Mag., IV, xliv, 104-117, August, 1872; Am. J. Sci., III, iv, 161-175, September, 1872.

Researches in actino-chemistry. Memoir second. On the distribution of chemical foree in the spectrum. Phil. Mag., IV, xliv, 422-443, December, $1872 ;$ Am. J. Sci., III, v, 25-38, January, 91-98, February, 1873.

\section{7.}

On the fixed lines in the ultra-red invisible region of the spectrum. Phil. Mag., V, iii, 86-88, February, 1877.

1879.

Political effect of the decline of faith in Continental Europe. Princeton Review, January, 1879.

On $a$ new form of spectrometer and on the distribution of the intensity of light in the spectrum. Am.J.Sci., III, xviii, 30-35, July, 1879; Phil. Mag., V, viii, 75-81, July, 1879.

1880.

On a new standard of light. Phil. Mag., V, ix, 76, Junuary, 1880.

Un the phosphorograph of a solar spectrum and on the lines in its infrared region. Proc. Am. Acad., xvi, 223, December, $1880 ; A m$. J. Sci., III, xxi, 171-183, March, 1881; Phil. Mag., V, xi, 157-169, March, 1881.

\section{II.-BOOKS.}

Elements of chemistry. By Robert Kane. American edition edited by John William Draper. One volume, 8vo., pp. 704, New York, 1842.

$\Lambda$ trentise on the forces which produce the organization of plants, with an uppendix. One volume, 4to., pp. 108, 216, New York, 1844.

Text-book on ehemistry. One volume, 12mo., pp. 412, New York, 1846.

Text-book on natural philosophy. One volume, 12mo., pp. 381, New York, 1847.

Human physiology—statical and dynamical. One volume, 8vo., pp. 649, New York, 1856.

History of the intellectual development of Europe. One volume, 8vo, pp. 631, New York, 1862.

Thoughts on the future ejvil policy of America. One volume, 8 vo., pp. 325 , New York, 1865.

A text-book on physiology. One volume, 12 mo., pp. 376, New York, 1866.

History of the American civil war. Three volumes, 8 vo., pp. 567, 614, 701, New York, 1867-1870. 


\section{NATIONAL ACADEMY OF SEIENCES.}

History of the conflict between religion and seience. One volume, $12 \mathrm{mo}$., pp. 373, New York, 1874.

Seientifie memoirs; being experimental contributions to a knowledge of radiant energy. One volume, 8 vo., pp. 473, New York, 1878.

\section{III.- LECTURES AND ADDRESSES.}

On the relations of chemistry to medicine. A lecture introductory to the course in chemistry, University of New York, medical department. Delivered November 1,1841 . 15 pages.

On the theory and phenomena of heat. The coneluding lecture of that part of the chemical course in the medical department of the University of New York. Delivered by Professor J. W. Draper, November 22d, 1841. 16 pages.

A valedictory lecture. Delivered in $\mathbf{M}$ areh, 1842. 14 pages.

On the relations of atmospheric air to animals and plants. A lecture introductory to the course on chemistry, medieal department, University of New York. Delivered Oetober, 1844. 16 pages.

On the relations and nature of water. Introductory lecture to the course on ehemistry, medieal department. Delivered November 1, 1845. 15 pages.

On the history of chemistry. An introductory lecture to the chemical course, medical department. Delivered October 30, 1846. 15 pages.

On phosphorus. An introductory lecture to the ehemical course, medieal department. Delivered October $30,1847.14$ pages.

On oxygen gas. An introductory lecture to the course in chemistry, medical department. Delivered October, 1848. 15 pages.

The influence of physical agents on life. An introduetory leeture to the course on ehemistry and physiology, medical department. Delivered Octotober, 1850. 14 pages.

The indebtedness of the eity of New York to its university. An address to the alumni at their twenty-first anniversary, held on the 28th of June, 1853. 30 pages.

The historical influence of the medical profession. An anniversary discourse. Delivered before the New York Aeademy of Medicine, December 10, 1863.32 pages.

Professional edueation. $\Lambda$ lecture introduetory to the eourse of 1869-'70 in the medical department. Delivered Oetober 18, 1869. 16 pages.

Address delivered to the $\Lambda$ meriean Union Academy of Literature, Seience, and $\Lambda$ rt at its first annual meeting, January 31,1870 . By J. W. Draper, president. 24 pages.

Seience in $\Lambda$ merica. $\Lambda \mathrm{n}$ inaugural address before the $\Lambda$ meriean ('hemieal Society. By Dr. John W. Draper, president. Delivered November 16, 1876. (Amencan Chemist, December, 1876; Am. J. Sci., III, xiii, 61-67, January, 1877.)

Evolution-its origin, progress, and consequences. $\Lambda \mathrm{n}$ address to the Unitarian Institute at Springfield, Mass., Oetober 11, 1877. Popular Science Monthly, December, $18 \pi 7$. 

THE UNIVERSITY LIBRARY

UNIVERSITY OF CALIFORNIA, SANTA CRUZ

SCIENCE LIBRARY

This book is due on the last DATE stamped below.

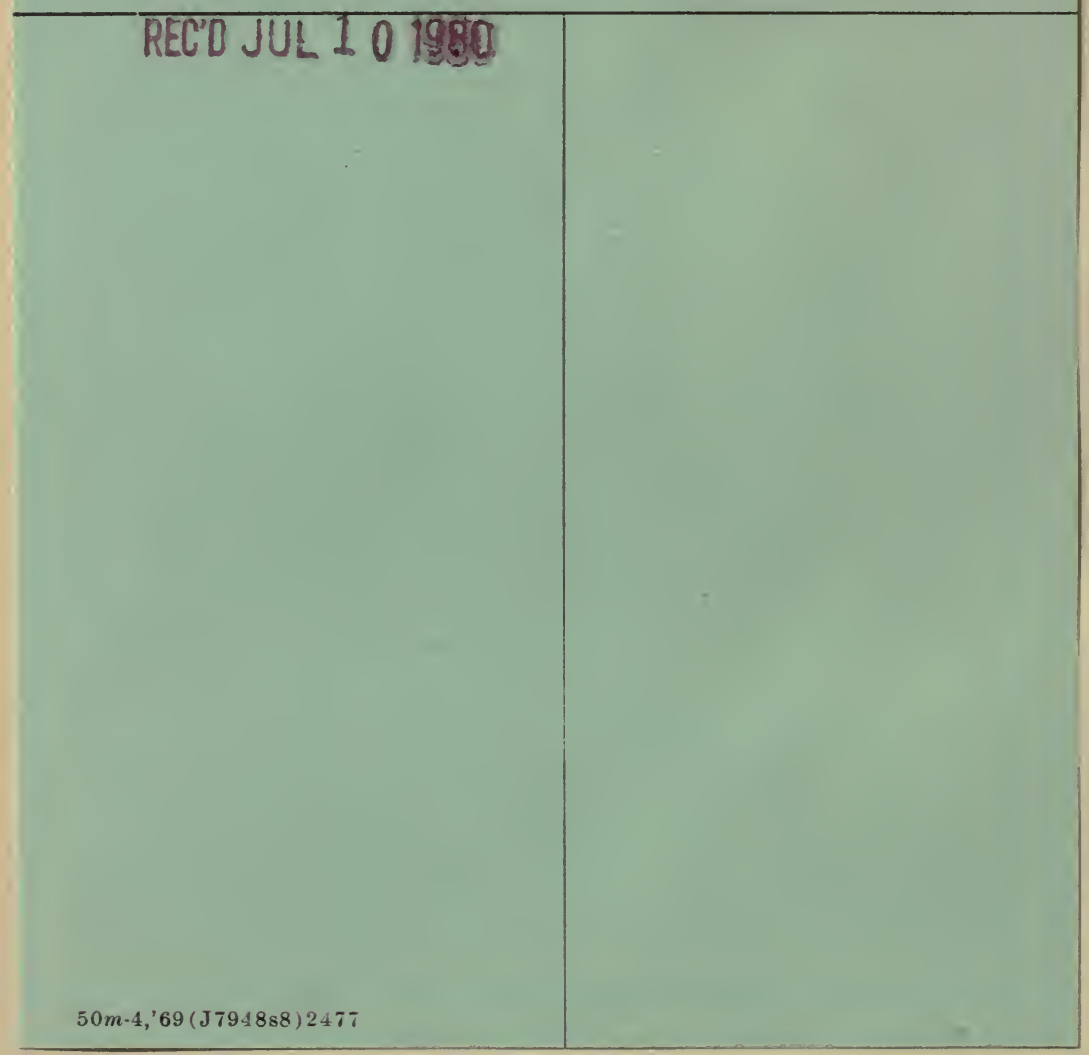




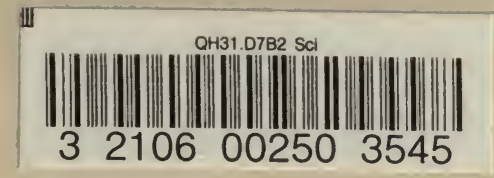


ans:

9.

Whos

108080

shosing

arosions

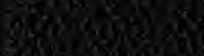

on vorays

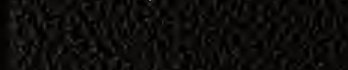

3.

3.

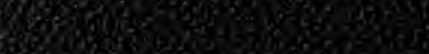

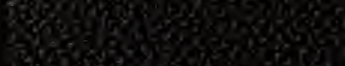

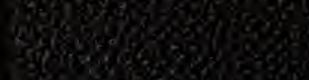

a

\%

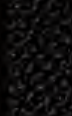

Hor

$\frac{60}{60}$

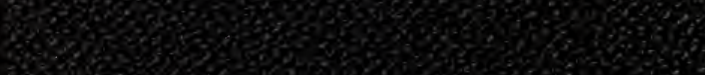

Fis

(3)

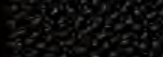

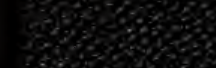

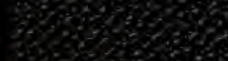

3. 